\title{
Problems in the Implementation of Javanese Language Teaching Administration During the Pandemic at State Junior High School 12 Yogyakarta
}

\author{
Mohamad Makincoiri*, Endang Nurhayati \\ Javanese Language Education, Faculty of Language and Arts, Universitas Negeri Yogyakarta, Indonesia \\ *Corresponding author. Email: mmakincoiri@gmail.com
}

\begin{abstract}
The Covid-19 pandemic has affected various fields, one of which is education. The shifts in teaching-learning patterns led to several changes and problems in the teaching and learning process, such as changes in the teaching administration. This research aims to describe problems in teaching administration of Javanese language subject during online teaching and learning at State Junior High School (SMPN) 12 Yogyakarta. This is a qualitative descriptive study. The data are the problems that occurred during the Covid-19 pandemic at SMPN 12 Yogyakarta The data were collected through field studies and analysed by using the literature study technique. The results of this study indicate that there are several problems regarding teaching administration during online teaching and learning that emerge due to the Covid-19 pandemic. The problems include the changes of the SKL (Standar Kompetensi Lulusan/graduate competence standard); changes in the one-year program and semester program; the limited methods for the assessment of knowledge, skills, social and spiritual competence, and the follow up program.
\end{abstract}

Keywords: Covid-19, Javanese language teaching, teaching administration

\section{INTRODUCTION}

Teaching administration is the main instrument that must be owned by teachers that are arranged individually or in groups [1]. Teaching administration is important because it is the basis for the learning process in one semester or one year. In establishing teaching administration, teachers set how the teaching-learning process will be carried out. Establishing teaching administration is one of teachers' main tasks and basic skills that teachers should have. Generally, establishing teaching administration should be conducted at the beginning of the school year, or at the beginning of the semester, and also throughout the teaching-learning process.

The aim of teaching administration is to guide the teaching-learning process so that learning objectives can be achieved [2]. Teaching administration contains plans for teaching preparation, teaching process, and assessment and evaluation process. By paying attention to these plans, teachers expect that teaching-learning processes can run smoothly. Because of the importance of teaching administration, it can be used as benchmarks to assess teachers' performance, because teaching administration is a concrete, tangible, and visible evidence. Schools and education agencies often facilitate teachers in establishing the teaching administration by conducting workshops, so that before the teaching and learning begins, the teaching administration is ready and can be used as a guide to carry out the teaching-learning process.

Teaching administration assessment is carried out by senior teachers or school principals through teacher supervision programs, principal work assessments, and school accreditation. This assessment is carried out to assess and evaluate teachers' performance during the teaching-learning process [3]. The one to be assessed is teachers' behavior and activities during daily teachinglearning processes [4]. The teaching administration assessment is done to assess teachers' performance, and also provide evaluations for a better teaching. 
Teachers' work can be said to be successful when they are able to make lesson plans, do the teachinglearning process, and assess the work and attitudes of students during the teaching-learning process [5]. Teachers' performance includes making lesson plans, doing the teaching-learning process and measuring students' learning outcomes or conducting assessments [6]. Based on this description, it can be concluded that teacher assessment is assessing the tasks or works that must be done by teachers.

The Covid-19 pandemic has caused many changes in people's daily lives. Changes must be implemented so that the pandemic will not get worse and can abate soon. In the new regulations, there are things that must be implemented, such as wearing masks, washing hands frequently, using hand sanitizers, and social restrictions. This situation caused several public places to be temporarily closed, including schools.

Because schools have been temporarily closed, there are changes in teaching-learning implementation such as online teaching-learning, changes in the time of the teaching and learning, and changes in teaching administrations. Online teaching and learning runs on a scale that has not been measured before, because there has never been an incident like this [7]. Because these changes arise from unforeseen circumstances, all of this changes are abruptly implemented led to the occurrence of problems at schools. One of the problems is about preparing teaching administrations in accordance with the Covid-19 pandemic.

This paper discusses the problems occurring due to online teaching and learning, especially in the implementation of teaching administrations. The institutions' request for teaching administrations has been partially changed in accordance with the Covid-19 pandemic. Teachers are asked to make teaching kits adapted to the pandemic situation, including the methods, steps, and strategies to be used [8].

Because of the changes, some teaching kits cannot be made as usual. This problem actually can still be changed so it can be run in the teaching-learning process. This changes in teaching and learning is expected to be a way to cope with the pandemic crisis. Online teaching is implemented to reduce physical contact to reduce the spread of the corona virus [9].

The aim of this study is to describe the problems that occurred during the online teaching, especially at SMPN 12 Yogyakarta. The result of this study is expected to be used as a comparison for the online teaching program in other subjects or schools.

\section{METHOD}

This research is qualitative descriptive in nature. The data are the teaching administration problems occurring during the Covid-19 pandemic. The data were described based on the literature study, and according to [10] this is considered as qualitative descriptive research. [11] writes that descriptive research describes or provides a systematic, factual, and accurate description of the facts in the data under study. In this research, the researcher described teaching administration problems occurring during the Covid-19 pandemic.

The data of this research are the problems that occurred in the implementation of teaching administration during the Covid-19 pandemic. They were taken from Javanese Language learning program at SMP N 12 Yogyakarta. This research was done through library research and field studies. The literature study was conducted to understand the theoretical basis and opinions of experts in education, and to find out the research results that were relevant to online learning during Covid-19 pandemic. The field studies were carried out to understand the problems that occurred in learning, especially those related to the implementation of learning tools. They were conducted at SMPN 12 Yogyakarta.

The data of this research were analysed using the descriptive analysis method by adding some statements or information about the learning problems during the Covid-19 pandemic. Data were collected by literature study and field observations. Data collection was done by using questionnaires for Javanese language teachers.

The data validation was done through sources triangulation. The data that had been obtained compared to other data from the other related subjects. Thus, it is expected that the data that had been found were valid.

\section{RESULT AND DISCUSSION}

There are various teaching administration activities that must be done by the teachers. Some of them must be made before teaching-learning activities begin, some must be made during the teaching-learning process. The teaching administration made before the learning process includes semester programs, one-year programs, syllabus, lesson plans, academic calendars, and SKL (Standar Kompetensi Lulusan/graduate competence standard) analysis. The teaching administration made during the learning process includes scores list, attendance, and daily test analysis.

All of these teaching administration activities are arranged in the teacher's workbook. Based on the regulation of the Ministry of Education No. 20 of 2016 about graduate competency standards for elementary and secondary education [12], there are four teacher workbooks, namely workbook 1, workbook 2, workbook 3, and workbook 4 . The workbooks are partly made by the vice principal for curriculum affairs, and partly made by the subject-matter teachers. Workbook 1 contains the analysis of SKL (Standar Kompetensi 
Lulusan/graduate competence standard), syllabus, lesson plans, and KKM (Kriteria Ketuntasan Minimal/minimum mastery criteria). All of this administration are made by subject-matter teachers. The teaching administration that must be made by subjectmatter teachers for workbook 2 are time allocation, oneyear program, semester program, and journal of teachers' agenda. The teaching administration that must be made by subject-matter teacherss for workbook 3 are students attendance, scores list, moral assessment, analysis of test results, improvement and enrichment programs, list of teacher and student handbooks, question grids, validation of questions, and analysis of items. While the teaching administration that must be made by subject-matter teachers for workbook 4 are follow-up programs and bibliography.

\subsection{Teaching Administration Problems in Teacher Workbook 1}

Teaching administration that must be made by subject-matter teachers for workbook 1 are SKL, analysis, syllabus, lesson plans, and KKM. The problems emerged due to the Covid-19 pandemic in teaching administration were the analysis of SKL, syllabus, and lesson plans. Due to the pandemic situation, Yogyakarta City Education Office gave an instruction to change the learning timetable. Lessons started at 07.30 and finished at 11.45. From this situation, the duration of lessons per week in all subjects was reduced. For Javanese language subject, which originally two lesson hours per week, it was changed to only one lesson hour per week.

Due to the reduction of lesson duration of Javanese language subject, several problems have occurred. In the SKL analysis, the amount of learning material delivered to students were not per normal, when the time given was still two lesson hours per week. Regarding this situation, the Education Office gave instruction for subject-matter teachers to map out the essential learning materials. Essential learning material map was an SKL analysis that had been adjusted to the duration of lessons per week, and according to the pandemic situation. Based on the pandemic situation, learning material to be delivered can be reduced, and indicators of competency achievement can be reduced.

Furthermore, the syllabus and lesson plans must be revised based on essential materials mapping. In the syllabus and lesson plans, it is written how the teaching steps are carried out. Due to the change in the duration of lessons per week for Javanese language subject, the way to convey teaching to students must be changed so that with a limited time, the learning material can be well accepted by students. Forty minutes or one lesson hour was not sufficient for teaching-learning processes, especially when it was done online. Some students were late when joining the online teaching and learning, so a lot of time was wasted. How to use time wisely and prepare students were the basic things so that teachinglearning process can run well and produce the desired results.

\subsection{Teaching Administration Problems in Teacher Workbook 2}

Teaching administration that must be made by subject-matter teacherss for workbook 2 are time allocation, one-year program, semester program, and journal of teacher's agenda. In the workbook 2, all administration document can be created and implemented properly. The time allocation, one-year program, and semester program are made based on the number of effective weeks that can be seen from the educational calendar.

The problem was that the revised education calendar was published a little late. The delay in educational calendar caused the making of the one-year programs and semester programs overdue, whereas the time allocation taken from the semester program was used to make time allocations in the syllabus and lesson plans.

\subsection{Teaching Administration Problems in Teacher Workbook 3}

Teaching administration that must be made by subject-matter teachers for workbook 3 are students attendance, scores list, moral assessment, analysis of test results, improvement and enrichment programs, list of teacher and student handbooks, question grids, validation of questions and analysis of items. The workbook is prepared before the teaching and learning process, and then partially filled out during the teaching and learning process.

The problem that occurred from the COVID-19 pandemic was the assessment method. Assessment is the process of collecting information by explaining evidence of measurement results, interpretations, statements, and interpretations of learning measurement results [13] Teaching and learning is an interaction between teachers and students in the form of theory and practice [14]. This statement is relevant with the statement that assessment is not only done to assess knowledge but also skills. Based on the assessment standards, the assessments include knowledge assessment, skills assessment, spiritual attitude assessment, and social attitude assessment. Each of these assessments has a variety of assessment methods that must be run by teachers.

In the knowledge assessment, the assessment models that must be done by teachers are written, spoken, and task assessments. Written assessments and task assessments can be done online. But the problem was that it was difficult to conduct an assessment with only 
one lesson hour per week. The speaking assessment took a long time, especially when it was done online. Unstable Internet connection often led to wasted time so that the assessment could not run well.

In the skills assessment, the assessment models that must be carried out are practice assessment, product assessment, project assessment and portfolio assessment. In the Covid-19 pandemic, practice assessments in Javanese language subject which was only given one lesson hour per week was difficult to conduct. Sometimes, the unstable Internet connection problem occurred during the practice assessment, so the practice assessment was done based on product assessments and project assessments that can be carried out by students outside the lesson. Student portfolio assessments were taken by student work that had been submitted via the Microsoft Teams App or Google Drive.

To conduct an assessment of social attitudes and spiritual attitudes, there are several ways such as personal self-assessment, peer assessment, and teacher observation journals. For social attitudes assessment and spiritual attitudes assessment conducted by personal self-assessment method with questionnaires and teacher observation journals. Assessment between friends could not be carried out because the interaction time among students was limited by time and media. The teacher's observation journal also could not be done optimally because students were not as active as they were in the offline learning.

\subsection{Teaching administration Problems in Teacher Workbook 4}

Teaching administration that must be made by subject-matter teachers for workbook 4 are follow-up programs and bibliography. At Junior High School of SMPN 12 Yogyakarta, the follow-up program was carried out by providing special assistance to students who have problems in online learning. This was done by providing computer laboratory facilities for students who did not have the devices to join online learning. For students who were often late in submitting assignments, a follow-up program was done by instructing students to attend school to conduct counselling with subject-matter teachers, homeroom teachers, and counselling guidance teachers. The bibliography used in this study was some books that had been given at the beginning of learning program and Internet sources. For the bibliography, there was no problem occurring during online learning.

\section{CONCLUSIONS}

The changes in the online teaching-learning processes have caused several problems, especially in the implementation of teaching administration. Some of these problems have been solved so the implementation of teaching administration could run well.

The problem occurred from online teaching and learning is the change in lesson duration of Javanese language subject that becomes one session per week. This causes problems in the teaching administration of Workbook 1, namely the syllabus and lesson plans.

Another problem is the assessment. Assessment models that can be done online are limited. Not all assessment models can be used in the online platform, because the lesson duration is limited to only one lesson hour per week, and also the interaction between teachers and students and among students themselves is limited. Assessments that cannot be held optimally are speaking assessments in knowledge assessment, practice assessments in skills assessment, and assessment of social attitudes and assessment of spiritual attitudes. The follow up program also needs more time.

For the better online teaching and learning, this teaching administration must be made varied, structured, and adjusted to the pandemic situation. Assessment can be varied, but it must be easy to work on with limited time.

\section{ACKNOWLEDGMENTS}

The Author would like to thank LPDP RI for providing tuition fees.

\section{REFERENCES}

[1] Nazirudin, Manajemen pembelajaran: implementasi konsep, karakteristik dan metodologi, Yogyakarta: Teras, 2007.

[2] Z. K Prasetyo, dkk., Pengembangan perangkat pembelajaran sains terpadu untuk meningkatkan kognitif, ketrampilan proses, kreativitas serta menerapkan konsep ilmiah peserta didik SMP. Yogyakarta: Program Pascasarjana UNY, 2011.

[3] S. Dharma, Manajemen kinerja: Falsafah teori dan penerapannya, Yogyakarta: Penerbit Pustaka Pelajar, 2005.

[4] M. Yamin, Maisah, Standardisasi kinerja guru. Jakarta: Persada Press, 2010.

[5] N. Sudjana, Dasar-dasar proses belajar mengajar, Bandung: Sinar Baru Algesindo, 1987.

[6] S. Arikunto, Manajemen pengajaran secara manusiawi, Jakarta: Rineka Cipta, 1993.

[7] R. H. S. Aji, Dampak covid-19 pada pendidikan di indonesia: Sekolah, keterampilan, dan proses pembelajaran. UIN Syarif Hidayatullah. Salam: Jurnal Sosial \& Budaya Syar'I Vol. 7, 2020, No. 5 Doi: https://doi.org/10.15408/sjsbs.v7i5.15314 
[8] M. Siahaan, Dampak covid-19 terhadap dunia pendidikan. Universitas Bhayangkara Jakarta Raya. Jurnal Kajian Ilmiah. Vol. 1 No. 1, 2020, Doi: https://doi.org/10.31599/jki.v1i1.265

[9] N. B. Argaheni, Sistematik review: dampak perkuliahan daring saat pandemi covid-19 terhadap mahasiswa Indonesia, UNS. Placentum: Jurnal Ilmiah Kesehatan dan Aplikasinya Vol. 8 No. 2, 2020 ,

Doi: https://dx.doi.org/10.20961/placentum.v8i2.43008

[10] L.J. Moleong, Metode penelitian kualitatif, Jakarta: Departemen Pendidikan dan Kebudayaan, 1988.

[11] M. Nazir, Metode penelitian, Jakarta: Ghalia Indonesia, 1999.

[12] Pemerintah Indonesi, Permendikbud No. 20 Tahun 2016 Tentang Standar kompetensi lulusan pendidikan dasar dan menengah. Jakarta: Direktur Jendral Peraturan Perundang-undangan Kementrian Hukum dan Hak Asasi Manusia, 2016.

[13] Fadillah, Implementasi kurikulum 2013 dalam pembelajaran SD/MI, SMP/MTS, dan SMA/MA, Yogyakarya: Ar-Ruzz Media, 2014.

[14] S. R. Putra, Desain belajar mengajar kreatif berbasis sains. Yogyakarta: Diva Press, 2013. 